\title{
Managerial Competencies and Venture Survival: The Case of Women Entrepreneurs Owner - Managers of Micro-Small Enterprises (MSEs) in Khartoum State - Sudan
}

\author{
Widad Ali A/Rahman \\ Associate Professor, School of Management Studies \\ Ahfad University for Women \\ Omdurman: P.O. Box167 \\ Sudan
}

\begin{abstract}
The objective of this study is to investigate the management competencies of female entrepreneurs, owner - managers of micro-small enterprises (MSEs) within urban settings in Khartoum State, Sudan. It addresses a knowledge gap in the literature regarding competencies of female entrepreneurs in Sudan. It is an exploratory study that follows an interpretive approach and applies Grounded Theory techniques. Five core competency areas are brought to focus based on previous competency models. The study findings elicit that competency levels possessed by owner-managers of (MSEs) vary according to the competency area, line of activity, type of venture and the attributes of the entrepreneur herself. Female entrepreneurs tend to adhere to a relational management style and a pragmatic approach, with high capacity to innovatively adjust to complex operational conditions, supported by their personal networks. Enhancing some competency areas through education and skill development programs is recommended to further ensure venture survival and success.
\end{abstract}

Keyword: Managerial competencies, Female entrepreneurship, MSEs, Resource-based theory, Venture Survival.

\section{Introduction}

It has been globally acknowledged that entrepreneurship and Micro-small enterprises (MSEs) play an important role in accelerating development and contribute to increased productivity, higher levels of employment and wealth creation of a nation (GEM Report, 2018).

In Sudan, women's work in general, and establishing business in particular are to a great extent shaped by the overall socio-cultural context. Despite diversity, this context is predominantly governed by a strict gender ideology where gender role divisions prevail and transcend the family and the household. This situation has its implications on women's engagement in productive economic activities, especially self-employment and establishing business.

However, in urban settings important transitions, are moderating the manifestations of this gender ideology, and play an important role in changing perceptions towards women's involvement in the economic sector. Thus, female entrepreneurship has flourished in Sudan, where considerable numbers of women-owned (MSEs) are concentrated in urban settings especially in Khartoum State.

Female entrepreneurship has grown in scope and complexity, displaying emerging themes that have been arousing interest among researchers. In this field, part of the international research included studies about female entrepreneurship contribution to economic development, factors and experiences of female entrepreneurs (Dvouletý\& Orel 2020; Tersoo, 2013; Bertaux and Crable, 2007; Botha et al. 2006), training programs interventions (Botha et al., 2006), characteristics and types of businesses run by female entrepreneurs; and necessity women- owned enterprises (Iakovidou et al., 2009; Hossain et al., 2009). Relatively, very scant research has been conducted on entrepreneurship in Sudan, with limited focus on female entrepreneurs. Examples of these studies include: Home-based women MSEs, those supported by Microfinance services in Omdurman (Pitamber, 2000); The Impact of Training on Women's MicroEnterprise (Leach et al. 2000); The Integration of Women-owned MSEs in Urban Markets in Khartoum State (A/Rahman, 2006); Women in food and beverages businesses in Khartoum (Badawi et al. 2008); Emerging Women Entrepreneurs in Sudan: Individual Characteristics, Obstacles and Empowerment (Musa, E. 2012); and Sudanese Women Entrepreneurship (Welsh and Memili,2013). Although these studies cover diverse areas of female entrepreneurship, none has focused on the 'how' dimension to which entrepreneurial competencies are main contributors. In assuming the managerial functions in their ventures, entrepreneurs are driven by the level of competencies they possess in the various operational fields such as finance, production, marketing, organizing and leadership. 
Despite a growing body of literature in the field of entrepreneurial competenciesglobally, (Baum and Locke (2004); Eysteinsson, and Guaugsson (2016); Mitchelmore, S. and J. Rowley, (2013), there is still a considerable gap of knowledge on entrepreneurial competencies of female entrepreneurship especially within the Sudanese context. Thus, the need arises for studies that can offer more insights and better understanding of female entrepreneurs' managerial competencies and how they influence ventures' performance that lead to venture survival and sustainability.

This study has been inspired by the Global Entrepreneurship Monitor (GEM) Sudan-2018 survey results which have revealed important information about female entrepreneurs in Sudan; one is the relatively high percentage (68\%) of the female participants informed that they perceive themselves to have the levels of knowledge and skills necessary to become entrepreneurs. Guided by the managerial competencies and skills which have been identified by some researchers (Baum and Locke (2004); Eysteinsson, and Guaugsson (2016); Mitchelmore and Rowley, (2013), this study aims to explore the managerial competencies that female entrepreneurs, owner-managers of MSEs, possess. It further aims to explore how do female entrepreneurs, perceive the managerial competencies necessary for them to function and assume their role as entrepreneurs/managers, and to what extent do they consider the survival of their ventures is attributable to the level of competencies they possess. The study focuses on women entrepreneurs, owners of MSEs within Khartoum State-Sudan, where most businesses and female entrepreneurs are concentrated (GEM Sudan,2018).

This study aims to contribute to extending the body of knowledge on female entrepreneurship by inclusion of managerial competencies of owner -managers of MSEs within resource-tight contexts like Sudan. This study is indeed significant because MSEs have been reckoned to serve large communal groups (Hameed, W. et al.2017) and are extensively significant for low-income and underprivileged communities as a powerful tool in eradicating poverty and beyond.

It has been observed that many female entrepreneurs are motivated to start businesses due to necessity (GEM Sudan, 2018). The fact that these MSEs have been characterized to heavily rely on the resources, characteristics and skills of the owners (Lerner, M. and Almor, T. 2002), managerial competencies become the prime focus of this particular study.

The structure of the remainder of this paper is as follows; First, a literature review argues the case for the importance of female entrepreneurship and the role of competencies in its development, and reviews previous theory and research on entrepreneurial managerial competencies. Next, the methodology for this research is outlined, followed by the results of the study and its interpretations highlighting core elements of Female Managerial Competence (FMC). Finally, the conclusion section summaries the contributions of this study and offer recommendations for practice and for further research.

\section{Literature Review}

\section{Managerial Competencies of Entrepreneurs}

In the literature, it has been indicated that entrepreneurs are responsible for establishing and running their start-up ventures where in many occasions they assume both entrepreneurial and managerial functions (Alvaro, et al.2007) especially in MSEs. This is why for an entrepreneur to succeed, he or she needs to practice basic business management principles. For MSEs to survive and respond to the competitive market conditions, owner-managers need management skills and production expertise that match their venture's type, scope and the available resources.

Entrepreneurs' Managerial Competencies are defined as integrated components of knowledge, skills and attitudes (Bird 2002; Man et al. 2002; Wagener et al. 2010; Volery et al. 2015). Man et al. (2002) defined entrepreneurial competencies as the total ability of the entrepreneur to perform a job successfully, which implies the interrelatedness of the entrepreneurial and managerial functions.

Boden \&Nucci, 2000 in Muhammad et al. (2015) defined managerial skills as the ability of an entrepreneur to execute the managerial roles, include marketing, financial management, book keeping and supervision. One distinctive study on female entrepreneurs' managerial competencies, Lerner and Almor (2001), differentiated between managerial skills (finance, human resource management, operations and strategic management), and entrepreneurial skills (innovation and marketing). In their classification of entrepreneurial and managerial competencies Lerner and Almor (2001) show that these sets of competencies are multidimensional, interrelated constructs that could be grouped in a variety of clusters. Smith and More (2005) identified two broad themes of managerial competencies; functional competencies such as marketing and finance, and organizational competencies such as the skills related to organizing and motivating, personal skills and leadership.

According to Mullins (2002), managerial skills are acquired than innate. Besides, managerial competencies are changeable, learnable and attainable through experience, training or coaching (Man et al., 2002; Volery et al., 2015; 
Wagener et al., 2010). This ascertains the need for better understanding of these features among female entrepreneurs to help design programs that enhance their managerial competencies, and consequently improve their performance.

\section{Female Entrepreneurship and the Role of Competencies}

Female entrepreneurship is now a buzz world. A significant number of women, 104 million, in 59 economies which represents more than 52 per cent of the world's population and 84 per cent of the world GDP embarked on new venture creation and development (GEM Report, 2018). Self-employed women comprise between 1.5 per cent and 45.4 per cent of the adult female population in their respective economies (Levie and Hart, 2012). Accordingly, women-owned businesses make an increasingly important contribution to these economies. Many of these businesses are micro-small enterprises (MSEs), and are more likely to start out of necessity and remain life-style businesses (GEM Report, 2018). Women-owned businesses are frequently sole proprietorships with limited number of employees and depend largely on the owner and her skills and competencies (Lerner et al., 1997 cited in Saffu and Manu, 2005). Interest in entrepreneurial and managerial competencies derives from the supposed link between competencies and the birth, survival and growth of a venture (Bird, 1995; Baum et al., 2001). There is evidence that understanding of the entrepreneurial managerial competencies in MSEs will support the development of competence, and will in turn have consequences on the survival and success of businesses (Churchill and Lewis, 1987; Low and MacMillan, 1988).

Within the entrepreneurship field research, scant focus is on the competency levels of female entrepreneurs. Some research findings suggest that women skills to manage financial and accounting operations are relatively weak compared to men (Stevenson, 1986; Collerette and Aubrey, 1990). Jennings and Cash (2006) note that there is a solid base of empirical research demonstrating gender variation in representation of some competency areas such as: developing social and human capital; motivations; goals; growth orientations; strategic choices; and acquiring and managing financial capital. Women in general are to a great extent disadvantaged due to the discriminative gender ideology which creates and perpetuates gender inequalities in the general spheres of women's lives. As a result, when women opt to entrepreneurship, they are more likely to be disadvantaged in their access to various entrepreneurial capitals, given their personal backgrounds, and the cultural context in which their businesses operate (A/Rahman, 2006; Carter and Shaw, 2006).

Chandler and Hanks (1994) drew the assumption that entrepreneurs need to be competent in two key roles; entrepreneurial (recognize and envision taking advantage of an opportunity) and managerial (acquire and utilize resources to co-ordinate the business interests and activities). Thus, there is a distinction between entrepreneurial and managerial behaviors, to assert that in managing a business, each behaviour complements the other, and that the ability to blend these two areas of competencies is crucial to organizational success. This study addresses female managerial competencies to bring gender implications on entrepreneurship practice, within a resource-tight context.

\section{Resource-based theory (RBT)}

The resource-based view of the firm (Barney, 1991; Grant, 1991; Peteraf, 1993), suggests that differences in business performance are related to the resources availed to the entrepreneur leading the venture, and the level of efficiency tomobilizeand utilizeresources. It is also suggested that the total assets of a firm comprise tangible and intangible resources (Wernerfelt, 1984), including competencies and capabilities.

Particularly, in the case of MSEs, the theoretical approach of RBT seems relevant primarily because in most contexts MSEs are under-resourced, and are likely to heavily rely on the owner'scharacteristics, skills and competencies to manage the scant resources available to them (Lerner et al., 1997 cited in Saffu and Manu, 2005). Hence, the RBT is deemed suitable since the majority of MSEs operate in tough environments and demand capable individuals (entrepreneurs/managers) with the appropriate competency to cope. As such, the survival of MSEs is perceived to be highly dependent on the competence endowments, unique managerial tactics and skills of the female entrepreneurs, and the resources at their disposal (A/Rahman, 2006).

\section{Methodology}

This study adheres to the Grounded Theory (GT) approach adopting an epistemological interpretive position, seeking to explain the phenomenon under scrutiny according to the perspective of the participants, without imposing external viewpoints formulated a priori (Strauss and Corbin,1967).

The study is conducted in Khartoum State, which constitutes the biggest business center in the country with the highest number of female entrepreneurs operating in different sectors(GEM-Sudan 2018). 
A non-probability, purposive sampling technique, based on theoretical saturation (Glaser,2002), has been utilized. Research sites were selected to achieve a diverse sample that provides many possibilities for comparison, which yields richer data (Glaser and Strauss, 1967; Strauss and Corbin, 1990). Focus has been on Total Early Stage Entrepreneurial Activity (TEA) and established businesses (those in business for more than 42 months) (GEM2018/19). The study focus is on female entrepreneurs especially those operating (MSEs), in traditional and non-traditional ventures. In this study, the key question is about the managerial competencies of female entrepreneurs, and how they perceive and experience the managerial role, and its influence on venture survival.

In-depth face-to-face interviews were planned for gathering data of the experiences of the recruited participant female entrepreneurs, since this tool allows the interviewees to report their experiences freely and flexibly (Glaser, 2002; Charmaz, 2006). Due to the COVID-19 pandemic, especially the lockdown and mobility restrictions, the interviews were conducted targeting each participant by on line interactive sessions, via 'skype' and 'what-sup video calls', after getting their consent. Each interviewextended to more than one hour, and some participants were interviewed twice to fill some data gaps. Since the interviews were conducted in Arabic (the local language), interview notes were professionally translated and transcribed soon after each round of interviews. This allowed the process of theoretical sampling to occur. Data analysis followed the paradigm model technique (Strauss and Corbin,1990). A coding process and memo writing went through identifying categories, and their dimensions (Strauss and Corbin,1990). The findings encompassed many categories which were reflective of what have emerged from the data. The line of reasoning and interpretations guided the findings towards the study objective of understanding how female entrepreneurs employ their managerial competencies and capabilities, to manage their businesses, to succeed and survive.

\section{Results of the study}

\section{Participants' Profile}

The majority of the participants fall in the age range (36-45) years old, all of them are university graduates within different specializations. All have diverse work experiences ranging between 2-5 years, except one who has deliberately never got employed. Half of the participants attended training courses, few of them relevant to entrepreneurship. Marital status and number of children are perceived important variables in shaping the experiences of female entrepreneurs. In total almost half of the participants were married with school-age children.

\section{Business profiles}

The majority of targeted businesses are in the service sector which resonates with the literature (e.g. GEM, 2018/19), almost all of the businesses are sole proprietorships, operating for a period between 2-8 years. This indicates that some are established businesses according to the GEM classification (42 months). Half of the businesses engage in traditional activities, those normally considered as women domains with activities relevant to the traditional gender roles of women. All businesses benefit from technology in operations and communications. As MSEs,most of these businesses offer limited job opportunities ranging between (1-9) persons.

\section{Domains of managerial competencies of female entrepreneurs}

This section exhibits the results of the study based on participants' narratives describing their behaviors when they assume the management role in their ventures. Major domains in the management competency have been identified comprising:1) Analytical and strategic competency, 2) Organizing \& leading Competency, 3) Business operational Competency, 4) Building relations and networking and, 5) Risk management Competency.

\section{Analytical thinking and strategic competency}

In this domain the participants expressed their perceptions on the strategic competence. All participants recognized the importance of strategic competence for successful management of their businesses. Some strategic behaviors were reflected by the data and compared to the literature (Man et.al 2002); 1) critical and analytical thinking, 2) conducting research 3) preparing and writing business plans, 4), formulating and implementing business processes, 5) make decisions quickly and proactively, 6) continuous assessment and evaluation, 7) making strategic adjustments.

The majority of the participants informed that they mostly analyze information about the business environment and market conditions, the customers, the macro economic conditions (such as exchange rate and inflation) ...etc. Theyfeel that they possess good analytical capacity that helps them to make better decisions and solve problems. However, only few (two) from those in non-traditional ventures have conducted marketing research, formulated written business plans, clearly developed and evaluated strategies based on this analysis. One participant who owns a Solar Energy Installment venture stated; 
"Good relationship with consultants in the field helped us to get information. We are well informed about the strengths, weakness, opportunities, and threats that the industry is bearing. Most information we get are related to market changes, best practices, and new opportunities". She added; "I did write our business plan. It's a living document, I keep updating it with the support of some friends and mentors".

One participant who owns a home-based retailing business informed;

"I think good capacity for information analysis helped me to keep the business going all these years. However, I don't write a plan, nor do I write strategies or work processes. It is all here(she points to her head), mentally I draw broad lines of what to do, depending on 'trial and error' in the implementation"(Retailor).

All the participants informed that they have high control over business activities, supported by good observation. The majority don't do marketing research, however they analyze market information and adjust their strategies accordingly. Many participants benefit from advice and guidance provided to them by family members, close friends and colleagues. Accordingly, they acknowledge the role of personal ties and relationships.

\section{Organizing \& leading competency}

This competency refers to the ability to organize and manage different internal and external resources. The interview data show that most ventures are micro in scope with limited numbers of employees, ranging between (1-9) persons. Thus, some elements of this competency were under-emphasized. Recruiting and training staff, especially in traditional venture types, mostly depend on the owner's family labor and flexible non-contractual recruitment to match the variation in business operations. One participant informed that;

"I have no staff recruitment policy... ...my husband doessome activities, for payment, however on non-contractual basis. Only a sort of agreement on what he commits to do. I don't trust others to be as committed to time and quality...so I prefer to do most things by the two of us" (Event Bakery Owner).

Most participants who are operating non-traditional ventures revealed a more structured organizing status, one of them stated:

"We hire an expert who deals with all HR issues. However, job description and hierarchical structures are usually not very complex and easy to follow. He tackles issues using a lean approach compatible with our venture's philosophy and scope"(Game Development Entrepreneur).

Almost all participants highlighted the ability to build teams and work together in harmony, especially for those with more than five employees. Some participants metaphorically informed of being bonded like a family, where cooperation and consideration for each other are common principles.

"We work as a family, and together we take the business towards success" (Beauty Therapist).

As for delegation and accountability, most participants informed thatthey often adopt a multi-tasking approach with good coordination to facilitate control. This is linked to the concept of motivation and rewarding which was more apparent in the non-traditional, more structured businesses with relatively more employees. The participants in these ventures commented on accountability and motivating employees by offering rewards and benefits including skill development opportunities. In traditional ventures, providing a 'caring' work environment that offers feelings of security and belonging to the business is perceived as a valuable reward especially for employees who need such motivation to facilitate for creating a balance between work and family responsibilities.

Some participants, in non-traditional ventures, explained that they opt to outsourcing for some business functions especially those of sophisticated technological/professional nature. This is due to issues of technical know-how and economic/financial limitations to meet the high cost of full-time recruitments of such experts. One participant informed;

"We have a limited operational base; we usually recruit people (engineers, consultants, ...etc.) based on project needs, while we obtain accounting and legal services through outsourcing for such professional functions. Other functions and day to day routine jobs are done by the entrepreneur herself" (Solar Energy Instalment,Owner). 
All participants consider organizing acquiring and coordinating internal and external resources a vital behavior for business survival. Almost all businesses are under-resourced which implies the need for good capacity to stretch the available resources to go a long way and contribute to efficient performance. The Event Bakery owner reflected how coordination and utilization of family resources are key to business operations;

"From day one of the business establishment I capitalized on family resources both tangible and intangible. Being a home-based business am managing space and utilities in a lucrative way for both family and business. However, sometimes it is hard to demarcate what goes for which. This needs good accounting capability so as not to inflate the business financial rewards. This requires good costing calculations" (Event Bakery Owner).

Another participant informed how she used family financial resources to expand her business. She informed;

"Financial resources are key to any business. I started with my own savings from a Rotating Fund 'ROSKASANDOG'. When I needed to expand my business by importing goods directly from Saudi Arabia and open a small outlet shop, I got financing from my brother who lately turned into a partner..." (Retailer).

One participant identified a capacity to utilize non-tangible (expertise) family resources to obtain business services such as accounting consultations. She informed;

"I do handle all accounting tasks related to the business using simple templates that I found online. However, when I need complicated tasks or professional advice I seek help from my brother who is an accountant" (Solar Energy Instalment Owner).

\section{Business operational competency}

This competency focuses on the capability of the participants to deal with operational aspects while assuming their managerial role of the quadrant business activities. The results from the interviews reflect the overall perceptions of the participants regarding their experience in business operations, highlighting some elements core to the managerial function. These elements are also mentioned by a variety of entrepreneurial competency models mainly the FEC (Michelmore and Rowley,2013). Three domains related to business operations capacity explored by this study comprise; 1) Business model development, 2) Managing financial resources, and 3) Marketing and innovation.

\section{Business model development}

Reference to the data, most participants informed that business operations and processes are centered around the entrepreneur herself, supported by knowledge, hobby and /or experience. The majority develop business models and prototypes based on the mentioned factors, based on market analysis. One participant narrated;

"The drive to start the business helped me to see what I intend to do within the broader market. I was overwhelmed by using my painting artistic talent and 'Hobby'. I started small, less formal, capitalizing on my mental capacity, motivated by feedback from those around me and their encouragement to creatively turn my hobby into business" (Event Bakery Owner).

Most participants perceive learning and experience as key to business process implementation, as explained by a participant running a non-traditional venture;

"From learning we improve our work, and by experience we change some processes. Training also helps in gaining technical know-how. In addition, we benefit of specialized experts in many aspects such as finance, accounting and prototype design (games). We as owners mostly focus on monitoring and control over the process" (Game Developer).

Further statements reflected how the participants create a prototype and design a product;

"We do understand the needs and the challenges that people face. So we choose the services that best match our clients' needs. Sometimes from customers' feedback, requests and orders we develop our ideas into products/services that solve customer' problems" (Agribusiness Consultant).

\section{Managing financial resources}

Two patterns of behaviors in dealing with financial management, depending on the type of venture (traditional/nontraditional), and the scope of the business operations, have emerged. The participants who are running traditional, micro and non-complex ventures tend to apply very simple financial techniques liable to 'trial and error', and gradually learning from experience. Most financial activities such as acquiring financial resources, budgeting, operating capital and debt management, are done with minimal book keeping or application of financial management models. Many have mentioned seeking help from family members and friends to resolve some financial issues. 
Others who operate more formal non-traditional ventures seemed to have better financial knowledge and skills since most participants have benefited from training opportunities and managed to apply self-learning, thus became capable to assume more sophisticated financial functions. Besides, they use outsourcing contracts to have more complex operations done by experts. The following statements reflect some participants' responses;

"I do some book keeping; I record fund sources and expenditure, very keen on a saving plan from revenues to maintain the business and as a cushion in case of risks. However, I hire experts for preparing financial /accounting documents" (Agribusiness Consultant).

"Personal savings is the best, easiest way to get funds. I keep daily records of sales vs costs, profit retained and working capital assigned, to feed into a monthly financial accounting. All is based on self- learning and training" (Owner of Fitness Center).

\section{Marketing competency}

Marketing competency is considered part of the functional managerial competency that entrepreneurs need to assume.This study intends to depict participants' capacity in understanding and applying the (4Ps) Marketing Mix framework.

Product development The results show some variation in the capacity for product development, and building a prototype. Some participants informed that they depend on customers' requests and the identification of what suits customers' credentials such as need, taste, preference and purchasing power. Others seem to innovatively modify available products and services to meet market demand and perceived opportunities.

"From experience, networks and connections with customers. we are guided to develop our offerings(Trader). Through customers'requests and orders we introduce specific products (Retailor). When developing/ improving our services we need to follow the rapid change in fashion and customers ' preference" (Beauty Therapist).

Most participants informed that they basically deal with products known in the market, but they change some product features or steps of the process;

"Products are not new, but the way I do business using social media is what is new.... also bringing a line of products from abroad upon customer's orders is a new trend in the retail market" (Retailor).

Only one participant who started, eight years ago, as a retailer in computer and communication services isfollowing a diversified product line strategy. Some years back she added mobile phones and accessories, and recently she engages in international 'Gold' trading. She classified herself as a 'True Entrepreneur';

"Selection of a product line which is innovative or different requires a good sense of the market needs, knowledge about advancements and offerings in the global markets and taking risks to introduce such offerings in the local market. That is how my venture moved from a local small communication service trading into international markets in a variety of products including gold" (Trader).

The participants who own non-traditional ventures and engage in new types of products such as entertainment educational services and musical shows expressed;

"Our business presents a new service in Sudan; offering educational entertainment through games and songs. Currently there are few competitors and our value proposition seeks and supports customer satisfaction" (Game Developer).

\section{Promotion strategies}

When asked about promotion strategies some anecdotes provided by the participants included;

"Being online home-based production entity, I rely on social media and word - of-mouth for advertising/ promotion. Other means are just too costly for the scope of my business" (Retailer).

"Since we deal in B2B transactions, we follow face-to-face promotional techniques" (Entertainment Venture Owner).

\section{Pricing strategies}

The participants perceive price strategies as crucial for business success, yet it is an area of differentiation. The majority stress the need to follow 'flexible' pricing and payment strategies that help maintain customers' loyalty and business viability simultaneously. The participants in traditional service ventures seem to be more customer-centric 
when setting prices, while those in non-traditional ventures focus more on competitors' prices, cost and return issues and profitability when setting price strategies. Following are some participants' reflections on this element;

"I don't set my prices in comparison to competitors at all, my customers are mostly aware that they get quality products which are by de-facto costly" (Event Bakery Owner).

"Each contract/project is different, so we follow price differentiation accordingly" (Solar Energy Installment Owner).

“When I set my price, I focus on customer's 'Purse' and financial capability, covering all costs and allowing a profit margin, I definitely don't follow a fixed price strategy" (Retailer).

\section{Distribution strategies}

Great variation was reflected by the interview data regarding distribution strategies adopted by participants in this study, mostly governed by the type of the products/services offered and the scope of transactions. Three commonly mentioned approaches to physical distribution by these MSEs are; 1) Project contracts for B2B targets, 2) Home-based ventures (Event Bakery and Retailer, using Online orders and direct home delivery or customer collection policy) and 3) service provision at business premises such as beauty and fitness centers, computer/communication services and business consultancy services. Some expressed by the following statements;

"We follow direct distribution \& personal selling to our clients" (Solar Energy Installation Business Owner).

"Orders are placed through telephone, or other social media channels. Customers collect their orders within seven days ...very prompt. Never failed an order" (Event Bakery Owner).

"Distribution is done through 'project' contracts, and conducting events" (Entertainment Venture Owner).

\subsubsection{Relationship competency}

The relationship competency refers to the human interaction between individuals within the business, both internally and externally. It shows a mix of communication and relationship building (Michelmore 2013). The study results show that the participants strongly associate with this competence, and most participants perceive themselves to have good communication and interpersonal capacity, facilitated by use of IT. Many participants moderately identify with negotiating capacity and perceive it as more relevant to Business-to-Business (B2B) transactions with high levels of financial investments and complex business contracts.

Networking and personal relationships gained consensus among all participants regarding their importance for managing MSEs. A number of advantages of networks and building relationships with people and organizations around the entrepreneurial venture were easily identified by the participants, such as;

"Through relations and networks businesses can have extra access to resources, identify opportunities, communicate information, use word-of-mouth and give feedback on venture performance. Sometimes network members can offer ideas and advice, also help entrepreneurs with their technical expertise and business support services" (Trader).

However, many participants highlighted some weakness in benefitting from what networking can offer. Some raised the issue of gender norms, attitudes and responsibilities that, in certain cases, limit women's capacity to build relations and networks.

"Relation building is core to doing business.... need to have good relations with all stakeholders involved, based on trust, respect and mutual benefits. It is important however, to draw the boundaries carefully and professionally, not much personalization when dealing with men, especially, being a woman. Some complications do come on surface...." (Retailer).

\section{Risk management competency}

The study results reveal that none of the participants mentioned having a risk management plan of any scope, though they have expressed knowledge of a bundle of risks associated with business practice; financial, operational, environmental,personal...etc. Most participants consider risk management as an area that needs capacity enhancement despite the ability of those who faced some risks to overcome the situations, as they informed. Many participants consider themselves lucky to have managed, so far, to deal with risks by themselves, while others appreciated advice and support offered by close members of their networks. Below are reflections made by some participants;

“Currently, we don't have a written risk management plan, but from experience and knowing the environment, e.g. energy cuts, seasonal drags and/or seasonal rush, we are prepared to some extent”" (Event Bakery Owner). 
"In business risk is inevitable, gain and loss always happen" (Retailer).

"In my case, the business engages in external dealswhere the currency exchange rate instability and inflation are the main threatening risks, in addition to petrol scarcity which disrupt delivery schedules" (Trader).

"I must say we are not 100\% proactive in risk management; our personal and cultural perspectives influence that. However, by experience we managed to overcome arising issues...." (Trader).

\section{COVID-19 Pandemic: Perceived risks and emerging opportunities for MSEs}

The world of work is being profoundly affected by the global COVID-19 Pandemic. The crisis has already transformed into an economic and labor market shock, impacting all businesses regardless of their size (ILO Report 2020). The interview results of this study show that the majority of the participants are aware of the impact of the pandemic; finance and liquidity constraints, severe decline in access to inputs of raw materials, great decline in customer demand for their products and services, disrupted marketing strategies and issues related to labor and staff obligations.

The participants highlighted some strategies that they have followed to mitigate the risks associated with COVID-19. Examples are; 1) discontinuity of business operations. 2) Home production and delivery based on customers' orders and collection, supported by IT and social media interactions. 3) Introducing new product lines such as health protection products (disinfectants and sterilization kits, face masks and PPEs). 4) Use of online marketing and ebusiness options. 5) Production of community awareness-raising materials (such as posters, pamphlets and musical video clips) informing the public about COVID-19, in addition to online trainings and sensitization on how to deal with the pandemic itself. Some participants informed;

"COVID-19 pandemic as an unthought-of risk has hit every level of business everywhere. To deal with it goes beyond individual business capacity...it is a true threat.... but people need to think of ways to survive" (Agribusiness Consultant).

“......Some small businesses shifted their activities toproducing health care supplies and awareness raising materials relevant to the pandemic. This type of work adopts a social perspective” (Beauty Therapist).

The participant who engage in entertainment service of 'Karaoke' event management services commented;

"COVID-19 pandemic will change the way of doing business in Sudan. Online platforms will be a main stream of service/product creation and delivery... a new online business sector will boom, and a huge part of micro-small traditional businesses will gradually vanish especially if this pandemic stood for a long time. My own business is harshly affected since the business mainly focuses on real-time experience and events targeting public gatherings" (karaoke Event Business Owner).

\section{Interpretations of the study findings}

The results of this study are organized in themes that emerged from three levels of data coding process (Straus and Corbin 1990), interpreted and conceptualized using theoretical sensitivity gained from consultation of literature and compared with some existing models of entrepreneurial competencies (Man, 2001; Man et al.2002; Mitchelmoreand Rowley,2013).

Five core themes are brought to focus by this study comprising the following competencies; (1) Analytical and strategic thinking; (2) Organizing and leading; (3) Business operations enforcement and implementations; (4) Personal Relations and networking; (5) Risk management.

Analytical and strategic thinking is the competency necessary for establishing, evaluating and executing strategies for entrepreneurial ventures (Man et.al 2002). Some variation regarding this concept is indicated according to the venture activity and type (traditional/non-traditional), the scope of operations and the attributes of the female entrepreneur leading the venture. For female entrepreneursrunning MSEs, analytical thinking proved to facilitate setting short-term more pragmatic and tactical actions than strategic planning. Some elements of the concept are least delineated such as conducting marketing research, writing strategic business plans or conducting systematic monitoring and evaluation. Dependence on 'mental documentation', 'trial and error' for both operational and strategic levels are common practice. This approach is not systematic and lacks clarity.Those with higher levels of human capital, acknowledgeanalytical thinkingenables them to better understand the conditions, respond to internal and external changes, identify problems and make better solutions. This highlights the significance of the concept and goes in line with the literature where the concept and its elements are highlighted as influential for venture performance and survival (Man et al.2002). 
The organizing competencies deal with the organization of different internal and external human, physical, financial and technological resources (Man et al. 2002). The perspectives of the female entrepreneurs in this study are consistent with prior research which posits that in most studied cases of MSEs, female entrepreneurs tend to manage away from the traditional command and control approaches (Buttner, 2001). It also explains the ability of female entrepreneurs to compromise contractual recruitment, structured division of tasks along formal hierarchies and formal motivation actions. These behaviors reflect lean delegation and accountability, and good locus of control skills.

Female entrepreneurs in MSEs ascertain strong reliance on personal relations in tackling managerial/organizational functions. Emerging perceptions of work relations within the business entity to resemble the 'family', where the role of the entrepreneur as 'nurturer' of employees, were highly emphasized. This implies that work relations bear connotations of care, forgiveness, learning, socialization, and trust. To make the balance between these connotations and basic managerial principles such as accountability, control and regulatory actions, female entrepreneurs have shown certain skills to mediate the relational impact.

A relational management style has emerged; certain dimensions (preserving, mutual empowering, and achievement focus) were identified albeit with variation, suggesting that female entrepreneurs running MSEs tend to adopt unique non-traditional command and control approaches; in line with findings by Buttner (2001) and A/Rahman (2006). Economic institutions at all levels; micro, meso and macro are gendered (Elson, 1995), thus female entrepreneurs in theseMSEs abide to gender norms and values which govern women's behavior. There have traditionally been gender differences in the power, roles and boundaries pertinent to female competence to organize and operate their ventures (Mitchelmore and Rowley, 2013). The approaches followed can be framed within the gender role division of reproduction and care for family members.

In female owned MSEs resource management and mobilization revealhigh dependency on family resources; financial and non-financial. This is mostly attributed to the business scope and level of 'informality', similar to findings by Ahmed (2007) where in a similar context, Malaysian entrepreneurs give high importance for receiving support and advice from members of their family, and family labor.However, in certain cases it flags a leadership competency shortfall of avoiding recruiting non-family members due to perception of mistrust in the capacity and commitment of non-family recruits. This indicates the need to learn more about how to communicate, negotiate and create relationships that enforce trust with employees (Man and Lau, 2005).

Many strategies to extend resources are in place such as resource leveraging. Since leveraging refers to doing more with less (Morris et al. 2002), these female entrepreneurs adopt various strategies to leverage their resources such as: using other peoples' financial resources (availing funds from 'ROSKAS'), using family tangible and intangible resources (assets and expertise) and using 'Gray marketing strategy' (in case of retail and trading ventures). The high level of efficiency these resources are mobilized and utilized enables the entrepreneurs to attain performance that lead to venture survival (Barney, 1991; Grant, 1991; Peteraf, 1993).

Business operations enforcement and implementations are perceived to be highly centered around the entrepreneur herself,supported by knowledge, hobby and /or experience, in line with the findings by (Lerner et al., 1997 cited in Saffu and Manu, 2005), Those with special talent, good education, significant human capital and work experience are more likely to perform well and survive. Learning from experience is considered key to successful business operations. Entrepreneurial learning from workplace experience is consistent with the assumption that entrepreneurs, especially successful ones, require a blend of analytical, creative, and practical aspects of intelligence which in combination constitute a special construct, 'successful intelligence' (Sternberg, 2003 cited in A/Rahman 2006). Knowledge gained in the workplace seemed to be discerned and highly valued in running the business. In such a case each move in the daily practice will be a 'building block' for a new developed type of business experience; "One gained knowledge about financing, a unique product or service, customer relations, marketing, accounting, dealing with employees and workers and other operational processes, none of this was part of our educational system learning...", one participant explained. This confirms the view in prior studies (Man et al., 2002; Volery et al., 2015; Wagener et al., 2010) which inform that managerial competencies are acquired and learned from education and training programs as well as from work experience.

This is also consistent with the study by Fenwick and Hutton (2000) which revealed that through learning processes women entrepreneurs craft their work environment, their purposes, and their ways to face challenges. It showed interconnection between technical, personal, and communicative knowledge unfolding the change that women experienced in the self, the environment and home, partly resulting from learning from the work experience (Fenwick and Hutton, 2000). 
However, knowledge and skills gained from experience seemed fluid, context ascribed, located in activity and supported by gained 'market relations'. A major disadvantage of this learning process is that it is not systematic and requires a long span of time to grasp even the fundamental elements of running the business. During such time some entrepreneurs may incur high costs of managerial mistakes and as one entrepreneur put it things appeared to be "in the grey zone, with a tendency for trial and error ". Nonetheless, the higher the capacity to learn from experience, the more likely are the chances to be successful in operating a business.

Gender, as a core attribute has its implication on the managerial competencies and behaviour since the gender ideology creates barriers to female engagement in entrepreneurship and to the advancement of themselves and their businesses. Some research findings suggest that women skills to manage financial and accounting operations are relatively weak compared to men (Stevenson, 1986; Collerette and Aubrey, 1990). However, this study has exhibited a capacity to strategize to bridge this gap through utilizing family members' expertise in the mentioned areas, and/ or by outsourcing to specialized entities. Gender disparities in representation of some competency areas such as: developing social and human capital; motivations; goals; growth orientations; strategic choices ...etc. have been highlighted by some studies (Jennings and Cash (2006). This current study paints somewhat a different picture where female entrepreneurs have managed to overcome the gender limitations and proved above threshold capabilities capitalizing on their human capital, work experience and in some cases hobby and artistic talents. In addition, overall contextual and socio-cultural transformations in the gender ideology have contributed to supporting successful cases.

Marketing competencies are crucial for entrepreneurial success in general and for female entrepreneurs in particular. While assuming the marketer's role, these female entrepreneurs proved to have the capability to respond to context and market dynamics, and successfully deal with complexities when applying the (4P) marketing mix approach (Kotler and Keller,2006; A/Rahman 2020). This has necessitated new conceptualizations of the marketing concept to be compatible with and adaptive to these conditions. Kotler (2001) suggests entrepreneurial marketing (EM) which is an integrative construct for understanding marketing in an era of change, complexity and in contexts with tight resource. EM incorporates the need for creative approaches to customer acquisition, retention and development. This has been apparent even in traditional ventures, despite the fact that most enterprises in this study were 'imitative'. Many entrepreneurs, however, have shown a capacity to creatively satisfy customers' needs, adapt to market changes and survive. In their case, creativity hardly imply introducing new products; rather it means modifying existing products and/or processes (Schumpeter 1934), management styles, mobilization of resources and utilization of indigenous processes.

Personal relations and networks have been perceived as instrumental for female entrepreneurs' success, and that maintaining networks is considered important for many reasons; it helps in,1) acquiring market and customer information, 2) identifying opportunities, 3) access to possible funding sources, 4) promotional activities, 5) recruitment of employees and 6) leveraging ventures' scarce resources by exploiting complementary resources and expertise.This is similar to findings byCarson et al. (1995); Hill (2000a); Hill and McGowan 1997 cited in Shaw (2004).

On the other hand, this is consistent with EM emotional dimensions, where marketing involves intuition, flair and insight instead of the rational aspects that underlie mainstream marketing theory. Thus, for both the marketer (female entrepreneur) and the customer, emotional and relational dimensions intermingle and determine the marketing behaviour of female entrepreneurs. Relational entrepreneurial competence is similarly identified by most competency models (Man 2001; Man et al. 2008; Michelmore \& Rowley 2013).

This study highlights the principle of reciprocity and the exchange of mutual benefits as the driving force for increased operationalization of the role of personal relations in economic actions. The pursuit of personal relations in the case of female owner-managers of MSEs does not limit itself to their customers, rather it extends to include: suppliers, colleague traders and government officials.

Risk taking competency is core in most entrepreneurial personality trait models (Gartner 1985, 1988; Gartner et al. 2013 cited in Antoncic et al. 2018). While risk management competency is vital for venture survival and success, the findings of this study ascertain that female owners of MSEs perceive risk as an inevitable factor surrounding all businesses. However, the capacity of entrepreneurs to deal with risks proved to be diverse. Personality attributes and cultural dimensions, especially fear of failure, have been highlighted as factors that shape risk perception, and the choice of a risk mitigation strategy. A common practice observed from this study is risk avoidance stemming from fear of failure and its implications; economically, socially and psychologically. This is similar to what the GEM study has revealed on the attitudes and perception of entrepreneurship within the adult population of Sudan (GEM Sudan National Report, 2018). 
COVID-19 pandemic has drastic risks on female entrepreneurs running MSEs. The most hit businesses are those in the service sector that require face-to-face interactions (such as beauty and fitness centers) and others that require big gatherings (such as trainings and entertainment events).

However, the study findings indicate that some opportunities have emerged as a result of the pandemic. Technological advancements, IT communications, digitalization and online services, have to a great extent, enabled businesses to utilize opportunities and survive. Technology has facilitated working from home, flexible hours and staff replacements contributing to cost balances. Strategies that have been adopted to mitigate the risks associated with COVID-19 pandemic have proven that most female entrepreneurs running MSEs are competent enough to adapt to adverse situations and innovatively cope.

\section{Conclusion and implications}

In conclusion, female owner-managers of MSEs in Sudan perceive managerial competencies essential to maintain good performance and to ensure venture survival especially in resource-tight contexts.

Analytical and strategic thinking proved to facilitate setting short-term more pragmatic and tactical actions than strategic planning. Organizing and leading competency has been exemplified by a relational management style suggesting that female entrepreneurs tend to adopt unique non-traditional least command and control approaches. Business operations enforcement and implementations are highly centered around the capabilities of the entrepreneur herself, supported by knowledge, hobby and learning from experience. Innovation in the case of female entrepreneurs running MSEs can be framed within Schumpeter's (1934) concept of creative destruction where product modifications, entering new markets, and using technology-supported processes satisfy the requirements for business model creativity. Marketing has been perceived as core to business success and survival. A relational approach to the marketing function was very apparent and has necessitated the adoption of entrepreneurial marketing (EM)as a conceptualization of the marketing competency of female entrepreneurs. Risk management competency is considered vital for venture survival and success, however, it is concluded that the capacity of entrepreneurs to deal with and manage risks proved to be diverse; mostly less proactive and less formal.

The study ascertains that in all competency areas, high dependency on networks and the relationships developed with individuals and institutions significantly help to fill some knowledge and skill gaps; to leverage resources and to offer support at critical decision points. Female entrepreneurs in MSEs in Sudan have strong pragmatic enforcement/implementation, networking and relational competencies that have significant effects on firm survival. Emphasis on willingness and capacity to maintain personal relations for business survival and success, is apparent. One entrepreneurflagged; "Personal relations and networks are valuable assets to the business that must be nurtured".

The study contributes to entrepreneurship literature within the context of Sudan. It may be 'comfortably' considered the first study that deals with competencies, and sheds light on the managerial component. Despite the limitations of this study, mainly being exploratory and covering narrow geographical and sectoral scopes, the findings touch upon important dimensions of the managerial competency and highlight competency areas to be enhanced. Some recommendations are suggested for example:

1)The government should enhance relevant elements of human capital through developing educational and training programs that incorporate entrepreneurship and management concepts across disciplines. 2)Female entrepreneurs should take advantage of skills development programs offered by government agencies and stakeholders.3)The government should assist MSEs by offering visible and accessible support services, 4)Relevant stakeholders should target potential entrepreneurs and equip them with the needed management skills in preparation for the start-up stage.

Further research is recommended to understand the dynamics and challenges facing female entrepreneurs managing non-traditional ventures at small and medium levels.

\section{References}

Ahmad, N., T. Ramayah, Wilson, Kummerow, L. (2010). Is Entrepreneurial Competency and Business Success Relationship Contingent Upon Business Environment: A study of Malaysian SMEs (Abstract). International Journal of Entrepreneurial Behavior \& Research, Vol. 16, No.3, pp. 182-203.

Álvaro, C., Domingo, R., Salvador, R. (Eds.) (2007). Entrepreneurship: Concepts, Theory and Perspective. Available:https://www.researchgate.net/publication/237632037. DOI: 10.1007/3-540-48543-0_1

Antoncic, J. A., Antoncic,B., Gantar, M., Bachkirov, A.A., Li, Z., Kakkonen, M. L.,Borges, P.P., Coelho, A. (2018). Risk-Taking Propensity and Entrepreneurship: The Role of Power Distance. Journal of Enterprising Culture, Vol. 26, No. 1 pp.1-26. World Scientific Publishing Company. DOI:10.1142/S0218495818500012 
A/Rahman, W. (2008). The Integration of Women-owned MSEs in Urban Markets in Khartoum State, PhD Thesis, Ahfad University for Women. Verlag, Berlin.

A/Rahman, W. (2008/9). Sudanese Women Entrepreneurs in Micro-Small Enterprises in Khartoum State (In Arabic), Bahithat, Vol XIII, Women and Money, pp 220 -244.

A/Rahman, W., Alshiekh, L., Mubashar, N., Alsaeed, M., Yassin, M. (2019). Global Entrepreneurship Monitor: Sudan National Report 2018/2019. [Online]Available:www.Gemconsortuim.org

Badawi, S., W. A/Rahman, A. El Jack, Lorenzel, G. (2008). Women in Food and Beverages Businesses in Urban Markets of Khartoum State. Working Paper 88, Humboldt University, Berlin. [Online]Available: https://www.econstor.eu/bitstream/10419/96465/1/615064582.pdf.

Barley, S., C. Moss, Saunders, P. (1987). Do Women Entrepreneurs Require Different Training? American Journal of Small Business, Vol.12(Summer), pp.27-35. [Online]Available:https://link.springer.com/chapter

Barney, J. (1991). Firm Resources and Sustained Competitive Advantage. Journal of Management, Vol. 17, pp. 99120. [Online] Available: http://dx.doi.org/10.1177/014920639101700108

Baum R. \& Locke, E. (2004). The Relationship of Entrepreneurial Traits, Skill, and Motivation to Subsequent Venture Growth. Journal of Applied Psychology, Vol. 89, No.4, pp. 587-598.

Bertaux, N. \&Crable, E. (2007). Learning about Women, Economic Development, Entrepreneurship and the Environment in India: a case study. Journal of Developmental Entrepreneurship, Vol.12, No. 44, pp.467-79.

Bird, B. (1995). Toward a theory of entrepreneurial competency. In: J.A. Katz and Blockhouse R.H (eds.), Advances in Entrepreneurship, Firm Emergence and Growth, Vol. 2. Jai Press, Greenwich, CT, pp. 51-72.

Bird, B. (2002). Learning Entrepreneurship Competencies: The Self-Directed Learning Approach. - International Journal of Entrepreneurship Education, 1, pp. 203-227.

Botha, M. (2006). Measuring the Effectiveness of the Women Entrepreneurship Program as a Training Intervention, on Potential, Start-up and Established Women Entrepreneurs in South Africa. PhD Thesis, University of Pretoria. [Online] Available: https://repository.up.ac.za/bitstream/handle/2263/29479/Complete.pdf?sequence=12

Baum, J.R. \& Locke, E.A. (2010). The Relationship of Entrepreneurial Traits, Skill, and Motivation to Subsequent Venture Growth. Journal of Applied Psychology. Vol. 89. No 4. pp587-598. [Online]Available:https://www.researchgate.net/publication/270820314 DOI: 10.1037/0021-9010.89.4.587

Buttner, E.H. (2001). Examining Female Entrepreneurs' Management Style: An Application of a Relational Frame. Journal of Business Ethics, 29, pp 253-269.Made available courtesy of SPRINGER VERLAG GERMANY: http://www.springer.com/philosophy/ethics/journal/10551

Carter S. \& Shaw, E. (2006). Women's Business Ownership: Recent Research and Policy Developments, Report to the Small Business Service. https://strathprints.strath.ac.uk/8962/1/SBS_2006_Report_for_BIS.pdf

[Online]Available:

Carson, D., Cromie, S., McGowan P. and Hill, J. (1995). Marketing and Entrepreneurship in SMEs, An Innovative Approach, Prentice-Hall, Englewood Cliffs, NJ.

Chandler, G. \& Hanks, S. (1994). Market Attractiveness, Resource-Based Capabilities, Venture Strategies and Venture Performance. Journal of Small Business Management, Vol. 12, No. 1, pp. 27-35.

Charmaz, K. (2006). Constructing Grounded Theory: A Practical Approach Guide. Sage Publishing Ltd, London.

Churchill, N. \& Lewis, V. (1987). The Five Stages of Small Business Growth. Harvard Business Review, Vol.3, No. 3.

Collerette, P. \& Aubrey, P. (1990). Socio-economic Evolution of Women Business Owners in Quebec. Journal of Business Ethics, Vol. 9, No. 2, pp. 417-422.

Dvouletý, O., \& Orel, M. (2020). What drives Female Entrepreneurship in African developing countries? In Dobson, S., Jones, P., Agyapong, D., Maas, G. (Eds.) Enterprising Africa. Routledge, (forthcoming). [Online]Available: https://www.researchgate.net/publication/

Eisenhardt, K.M. \& Martin, J.A. (2018). The Importance of Entrepreneurial Competencies on The Performance of Women Entrepreneurs in South Africa. The Journal of Applied Business Research, Vol.34, No. 2.

Elson, D. (1995). Gender Awareness in Modeling Structural Adjustment. World Development Volume 23, Issue 11, pp. 1851-1868.[Online]Available: https://doi.org/10.1016/0305-750X(95)00087-S

Eysteinsson, F. \&Gudlaugsson, T. (2010). The Essential Competencies of Marketing Managers in Retail Firms. The European Institute of Retailing and Services Studies.pp.1-16. [Online] Available: https://notendur.hi.is/th/efni/Eirass 10a.pdf

Fenwick, T. J., Hutton, S. (2000).Women crafting new work: the learning of women entrepreneurs.(Abstract). [Online]Available: http://hdl.voced.edu.au/10707/80551

Gartner, W.B. (1985). A Conceptual Framework for Describing the Phenomenon of New Venture Creation. Academy of Management Review.10 (4): pp 596-606. 
Glaser, B. \& Strauss, A. (1967). The Discovery of Grounded Theory: Strategies for Qualitative Research. New York: Aldine de Gruyere.

Glaser, B. (2002). Conceptualization: On Theory and Theorizing Using Grounded Theory. International Journal of Qualitative Methods, Vol.1, No. 2. Article3. [Online] Available: https://www.google.com/search?client=firefox-b-d\&q=Glaser\%2C+B.+(2002).Global Entrepreneurship Monitor Report, GERA Consortium, 2018. [Online] Available: www.geraconsortuim.org

Grant, R. (1991). The Resource-based Theory of Competitive Advantage: Implications for Strategy Formulation. California Management Review, Vol. 33, No. 3, pp.114-135.

Hameed, W.U., Azeem,M., Ali, M., Nadeem, S., Amjad, T. (2017). The Role of Distribution Channels and Educational Level Towards Insurance Awareness Among the General Public. International Journal of Supply Chain Management. Vol. 6, No 4. Pp 308-318.

Hayton, J. \& Kelley, D. (2006). A Competency-based Framework for Promoting Corporate Entrepreneurship. Human Resource Management, Vol. 45, No. 3, pp. 407-27.

Hossain, S. M. Abu Saleh, Drennan, J. (2016). A Critical Appraisal of the Social Entrepreneurship Paradigm in an International Setting: a proposed conceptual framework. Springer Science +Business Media, New York.

ILO Monitor (2020). COVID-19 and the world of work. Fourth edition Updated estimates and analysis. [Online]Available: https://www.ilo.org/wcmsp5/groups/public/

Jennings, E. \& Cash, M. (2006). Women's Entrepreneurship in Canada: Progress, Puzzles and Priorities. In Brush, Candida G. et, al. Growth-oriented Women Entrepreneurs and their Businesses. Northampton, MA: Edward Elgar Publishing, pp. 53-87.

Kotler, P. (1992). Marketing for Congregations: Choosing to Serve People More Effectively. Nashville. TN: Abingdon Press.

Kotler, P. (2001). A Framework for Marketing Management. Prentice Hall.

Kotler, P. and Keller, K. (2006) Marketing Management. 12th Edition, Prentice Hall, Upper Saddle River. [Online]Available:

https://www.scirp.org/(S(vtj3fa45qm1ean45vvffcz55))/reference/ReferencesPapers.aspx?ReferenceID=175596 0

Lakovidou, O., Koutsou, S. Partalidou, M. (2009). Women Entrepreneurs in the Greek Countryside: A typology according to movies and business characteristics. Journal of Developmental Entrepreneurship, Vol.14, No.02, pp.165-179.

Leach, T. \& Kenny, B. (2000). The role of Professional Development in Simulating change in Small Growing Businesses. Continuing Professional Development, Vol.3, No. 1, pp 7-22.

Lakuma, C. \& Sunday N. (2020). Impact of COVID-19 on Micro, Small, and Medium businesses in Uganda. [Online]Available: https://www.brookings.edu/blog/africa-in-focus/

Lerner, M. \&Almor, T. (2002). Relationship among Strategic Capabilities and the Performance of Women-owned SMEs. Journal of Small Business Management, Vol.40, No, 2, pp. 109-125.

Levie, J. \& Hart, M. (2012). Global Entrepreneurship Monitor. United Kingdom, 2011 Monitoring Report. [Online]Available:www.gemconsortuim .org

Lopa, N. \& Bose, T. (2014). Relationship Between Entrepreneurial Competencies of SME Owners/managers and Firm Performance: A study on Manufacturing SMEs in Khulna City. Journal of Entrepreneurship and Management, Vol.3, No. 3.

Low, M. \& MacMillan L. (1988). Entrepreneurship: Past Research and Future Challenges. Journal of Management, vol.14, No.2, pp139-161. [Online]Available: https://www.researchgate.net/publication/246075266

Man, W.Y.T. (2001). Entrepreneurial Competencies and the Performance of Small and Medium Enterprises in the Hong Kong Service Sector. Doctoral Dissertation, The Hong Kong Polytechnic University. https://doi.org/10.1080/08276331.2008.10593424

Man, T. \&. Lau, T. (2005). The context of Entrepreneurship in Hong Kong: An investigation through the patterns of entrepreneurial competencies in contrasting industrial environments. Journal of Small Business and Enterprise Development, Vol. 12, No.4, pp.464-481. [Online]Available: https://doi.org/10.1108/14626000510628162

Man, W.Y.T., Lau, T., Snape, E. (2008). Entrepreneurial Competencies and the Performance of Small and Medium Enterprises: An Invest Through a Framework of Competitiveness. [Online]Available: https://www.researchgate.net/publication/271822402. DIO:10.1080/08276331.2008.10593424

Mitchelmore, S. \& Rowley, J. (2013). Growth and Planning Strategies within Women-led SMEs. Management Decision.Vol.5, No. $\quad$ 1, $\quad$ p. http://genet.csic.es/sites/default/files/documentos/biblioteca/Mitchelmore\%20Growth\%20and\%20planning.pdf 
Mitchelmore, S. and Rowley, J. (2013a). Entrepreneurial Competencies of Women Entrepreneurs Pursuing Business Growth. Journal of Small Business and Enterprise Development, Vol. 20, No.1, pp.125-142. [Online] Available: https://doi.org/10.1108/14626001311298448

Morgan, N., C. Katsikeas, D. Vorhies, (2012). Export marketing strategy implementation, export marketing capabilities, and export venture performance. Journal of the Academy of Marketing Science, Vol.40, No.2, pp. 271-289. [Online]Available: https://www.researchgate.net/publication/225441763

Morris, M.H., Schindehutte, M. (2002). Entrepreneurial Marketing: A Construct for Integrating Emerging Entrepreneurship and Marketing Perspectives. The Journal of Marketing Theory and Practice, 10. (4).19. [Online]Available:https://www.researchgate.net/publication/257926297DIO:10.1080/10696679.2002.1150192 2

Muhammad, K., Kazimbo, S., Semugenyi, F. (2015). Managerial Skills and Success of Small-Scale Entrepreneurs in Kampala, Uganda. Canadian International Journal, Social Science and Education Vol 3, pp 1-30. [Online] Available: https://www.researchgate.net/publication/338294015

Musa, E. (2012). Emerging Women Entrepreneurs in Sudan: Individual Characteristics, Obstacles and Empowerment. ICBE-RF Research Report No. 33/12, 2012. Investment Climate and Business Environment Research Fund (ICBE-RF). [Online] Available: www.trustafrica.org/icbe.

O'Dwyer, M., Gilmore, A., Carson, D. (2009). Innovative marketing in SME. European Journal of Marketing 43(1/2). pp46-61.[Online]Available:https://www.researchgate.net/publication/242342112.

DOI:10.1108/03090560910923238

Peteraf, M. (1993). The Cornerstones of Competitive Advantage: A resource- based view. Strategic Management Journal, Vol.14, No 3. [Online]Available: https://doi.org/10.1002/smj.4250140303

Pitamber, S. (2000). Accessing Financial Resources and Entrepreneurial Motivation Among the Female Informal Sector Micro-entrepreneurs in Sudan. The Ahfad Journal, Vol.17, No.1.

Pollard, R. (2006). Women entrepreneurs: How important are their perceptions? Academy of Entrepreneurship Journal, 12(1), 1-18. Google Scholar

Priem, R. \& Butler, J. (2001). Is the Resource-Based 'View' a Useful Perspective for Strategic Management Research? The Academy of Management Review, Vol. 26, No. 1, pp. 22-40.

Saffu, K. \& Manu, T. (2004). Strategic Capabilities of Ghanaian Female Business Owners and the Performance of their Ventures. [Online] Available: https://www.researchgate.net/publication/251891526

Schumpeter, J. (1934). The Theory of Economic Development. Cambridge, MA: Harvard University Press.

Shaw, E. (2004). Marketing in the Social Enterprise Context: Is it Entrepreneurial? Qualitative Market Research,Vol. 7, (3). pp.194-206.

https://pdfs.semanticscholar.org/7bcd/b40f1f77a6984c50d31511794e6387616930.pdf

[Online]Available:

Smith, B., \& Morse, E. (2005). Entrepreneurial Competencies: Literature Review and Best Practices. Small Business Policy Branch, Industry, Canada, Ottawa.

Stevenson, L. A. (1986). Against All Odds: The Entrepreneurship of Women. Journal of Small Business Management. (Preview). [Online]Available: https://www.questia.com/read/1G1-4587542/

Stevenson, H. \&Jarillo, J. (1986). Preserving Entrepreneurship as Companies Grow. Journal of Business Strategy, Vol. 6, pp. 10-23.

Stevenson, L. (1988). Women and Economic Development: A Focus on Entrepreneurship. Journal of Development Planning. No. 18: pp 113-125.

Strauss, A. \& Corbin, J. (1990). Basics of Qualitative Research: Grounded Theory Procedures and Techniques. Newbury Park, CA: Sage.

Tehseen, S. \&Ramayah, T. (2015). Entrepreneurial Competencies and SMEs Business Success: The Contingent Role of External Integration. Mediterranean Journal of Social Sciences, MCSER Publishing, Rome-Italy, Vol. 6, No. pp. 50-61. [Online]Available: https://www.researchgate.net/publication/272641875

Wagener, S.L., Gorgievski, M.J., Rijsdijk,S.A. (2008). Businessman or Host? Individual Differences between Entrepreneurs and Small Business Owners in the Hospitality Industry. Erasmus Research Institute of Management (ERIM), Erasmus. [Online] Available: www.erim.eur.nl.

Welsh, B. \& Mimili, S. (2013). Sudanese Women Entrepreneurs. Journal of Developmental Entrepreneurship, Vol.18. No.2. World Scientific Publishing.

Wernerfelt, B. (1984). A Resource-Based View of the Firm. Strategic Management Journal, Vol. 5, No. 2, pp.171-180. [Online] Available: https://onlinelibrary.wiley.com/doi/abs/10.1002/smj.4250050207

Wheadon, J. \&Duval-Couetil, N. (2014). Business Plan Development Activities as a Pedagogical Tool in Entrepreneurship Education. The Journal of Engineering Entrepreneurship. Vol, 5 (1). [Online]Available: https://www.researchgate.net/publication/263547863DOI:10.7814/jeen5v5p3wd. 